\title{
RESEARCHES ON THE USE OF AIR FILTRATION ELEMENTS IN THE CREATION OF MICROBUBBLES FOR WATER OXYGENATION
}

\author{
Prof. Nicolae Băran, PhD Eng. ${ }^{1}$, George Marin, MSc. Student Eng. ${ }^{2}$, \\ As. Mihaela Constantin, PhD Eng. ${ }^{3}$, Rareș Păun, PhD Student Eng. ${ }^{4}$, \\ Albertino Roza, PhD Student Eng. ${ }^{5}$ \\ 12345 Politehnica University of Bucharest \\ Splaiul Independenței, $n r$. 313, sector 6, Bucharest \\ inregistrare@gmail.com
}

\begin{abstract}
The air filtering device allows the airflow at the exit of filter cartridge to generate very small bubbles called microbubbles $(\varnothing<100 \mu \mathrm{m})$. The size of the air bubble injected into the water tank depends on the orifice size in the microbubbles generator perforated plate. The paper presents the theoretical and experimental researches results on the use of air filtration cartridges to the achievement of micro air bubbles.
\end{abstract}

Keywords: Micro Filters, Fine Bubbles Generators, Water Oxygenation, Micro Air Bubbles, Microbubbles Generator.

\section{Introduction}

The construction of high-performance filtering elements involves the development of unconventional technologies that pursue the following objectives:

- achieving a very high execution precision;

- Performing complex geometries of complex assemblies;

- processing of materials in order to obtain structures with complicated architecture

To obtain fine bubbles or microbubbles, the diameter of the orifices should be as small as possible $(\mathrm{d} 0<1 \mathrm{~mm})$ and the distribution of the orifices in the plate should be uniform.
These two conditions can be achieved with the help of advanced technologies or modern microprocessing technologies [1] [2] [3]:

- Spark erosion processing;

- Electrochemical processing;

- Laser processing;

- Electron beam processing;

- Drills in coordinate, with $\emptyset 0.5 \mathrm{~mm}$ drills.

The gas bubbles immersed in water to increase the dissolved oxygen content of water come from the following sources:

- Atmospheric air (21\% $02+79 \%$ N2);

- A mixture of atmospheric air and oxygen from the cylinder;

- Low nitrogen-containing air from oxygen concentrators.

These gas bubbles can be classified as follows (Fig. 1):

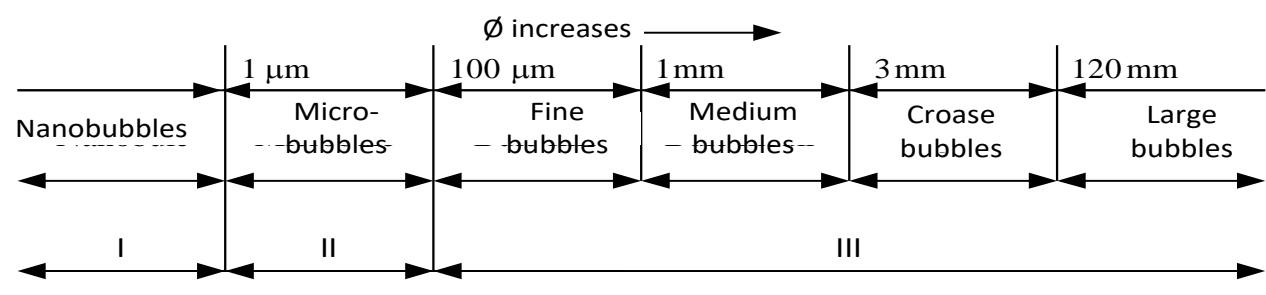

Figure 1: Classification of gas bubbles according to their diameter ( $)$ ): I - the area where the gas bubbles can be observed under the microscope;II - the area where gas bubbles can be observed with difficulty;III - the area where gas bubbles can be observed with the naked eye 
The filtering process refers to liquids and gases; the present work only refers to gas. In principle, an effective filtration of a gas stream follows the absorption of toxic gases, acidic, basic, particles and aromatic compounds (odors).

The gas filtering action applies to buildings, offices, hospitals, museums, factories, transportation facilities, ships, airports, mines, etc.

\section{The Use of Micro Filters for the Production of Air Microbubbles}

It is known from the literature [4] [5] [6] that the lower the diameter of the air bubble in the water, the higher the rate of oxygen transfer to the water. As a result, air filter elements will be used to generate air bubbles with a small size as possible at the outlet.

For microbubbles generators (MBG), the diameter of the air bubble (D0) introduced into the water tank depends on the diameter of the orifice (d0) in the perforated plate (D0> d0). When using air filters, the diameter of the air bubble will be given by the diameter of the orifices in the filter cartridge. The filter cartridge will be inserted into the water and connected to a compressed air line; hence it must be built of steel.

From the literature [7] [8] there are different types of filters made of stainless steel; so, in Fig. 2 there is a filter cartridge produced in Canada [8], which is made in several constructive versions.

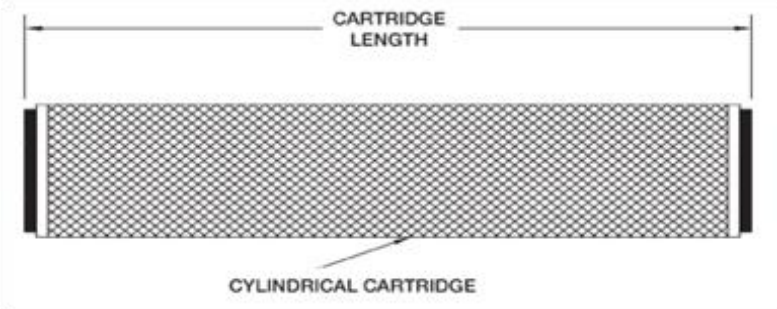

Figure 2: Filter cartridge [8]
- Orifices size: $2,5,10,20,40 \ldots 840 \mu \mathrm{m}$;

- Cartridge length: 10", 20", 30", 40";

- Fluid temperature: up to $2600 \mathrm{o}$;

- Flow volume: $0 \div 37 \mathrm{dm} 3$ / min;

- Pressure drop: $0 \div 0.14$ bar $=1400 \mathrm{~mm} \mathrm{H2O}$;

Use of this filter cartridge occurs in the following cases: viscous fluids, corrosive fluids, oils, water treatment, chemical solutions, fluids with temperatures below $260 \mathrm{oC}$, etc.

\section{The Use of Microbubbles Generators}

Compared with the performance of some micro filters, micro bubbles generation is being analyzed. The author's research has led to the development of a MBG in which the perforated plate has orifices with $\mathrm{d} 0=100 \mu \mathrm{m}$. Figure 3 shows a general view of the MBG.

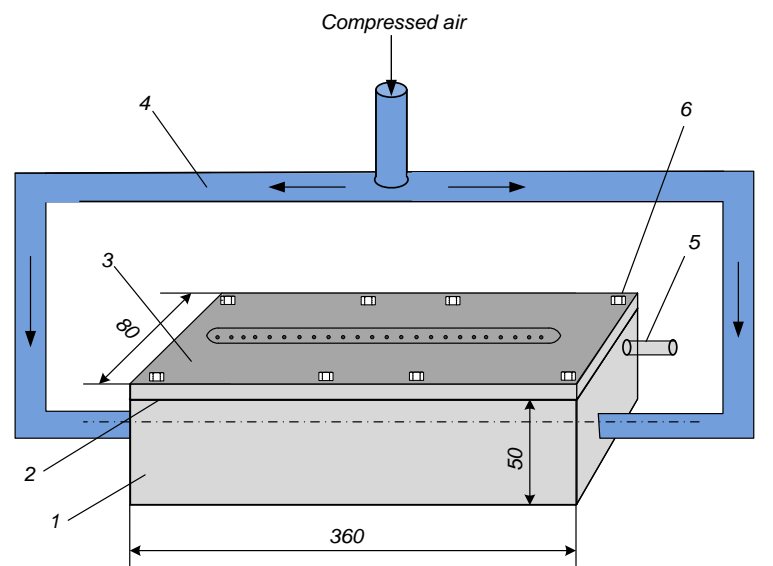

Figure 3: Air microbubbles generator: 1 - compressed air tank; 2 - sealing gasket; 3 - the orifice plate;

4 - Ø 18 mm pipe with compressed air; 5 - connection for the measurement of the air pressure in the tank; 6 - perforated plate fastening screws

Generally, these constructive versions have technical data in the areas of:

A rectangular shape plate was chosen as a design. An outline of this plate is shown in Figure 4.

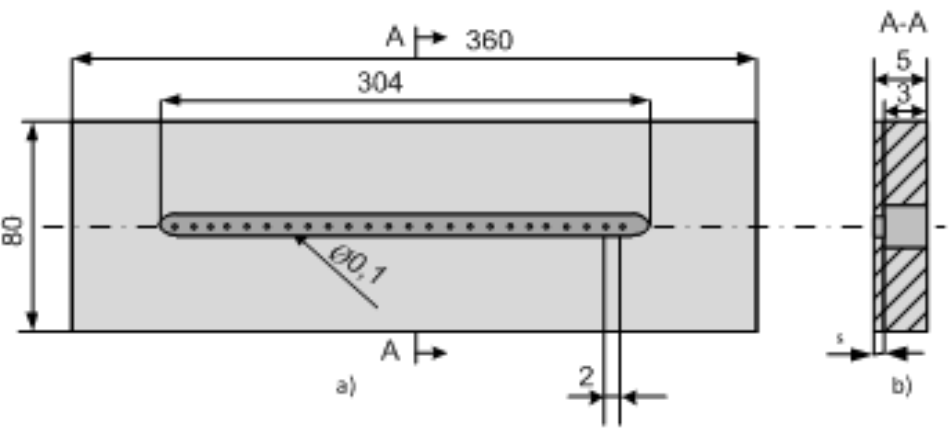

Figure 4: The orifice plate of MBG: plan view; b) cross section 
To form the orifices in the plate (Fig. 4), a $3 \mathrm{~mm}$ depth and $304 \mathrm{~mm}$ long alveolar channel was created; the outlet through which the air exits has a thickness of $2 \mathrm{~mm}$.

Later, with a C.N.C. which has a special KERN Micro microprocessor machine was made in the channel with 152 orifices $\emptyset 0.1 \mathrm{~mm}$.

Experimental researches has determined the pressure drop $\Delta \mathrm{p}$ to the passage of air through this MBG.

Air pressure at MBG entrance must overcome the hydrostatic load, superficial tension and pressure losses that occur when air passes through the orifice plate [9] [10].

\section{Determination Of Pressure Losses at the Microbubbles Generator}

The 152 orifices being distributed in parallel, the loss of pressure on each will be equal. Figure 5 shows a schematic diagram for determining pressure losses at the MBG [11].

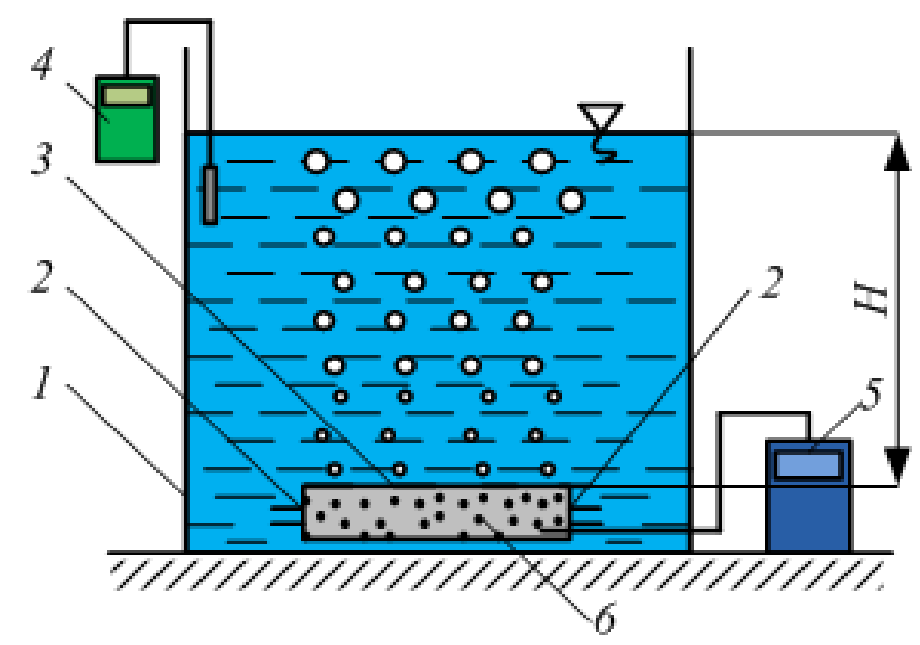

Figure 5: Scheme for measurements: 1 - water tank; 2 - compressed air inlet connection; 3 - the plate orifice; 4 digital thermometer; 5 - digital indication manometer; 6 - MBG body

The compressed air pressure in the tank (6) is p1 and it must cover:

$$
\mathrm{p}_{1}=\mathrm{p}_{\mathrm{H}}+\Delta \mathrm{p}_{\mathrm{ts}}+\Delta \mathrm{p}_{\mathrm{p}}
$$

$\mathrm{p}_{\mathrm{H}}$ - hydrostatic load, $\mathrm{H}=500 \mathrm{~mm} \mathrm{H}_{2} \mathrm{O}$; tension;

$\Delta \mathrm{p}_{\mathrm{ts}}$ - loss of pressure to overcome superficial

$\Delta \mathrm{p}_{\mathrm{p}}$ - the pressure drop that occurs when the air passes through the orifice to the dry plate.

From experimental measurements resulted:

$\mathrm{p}_{1}=583 \mathrm{mmH}_{2} \mathrm{O}$;

$\mathrm{p}_{\mathrm{H}}=500 \mathrm{mmH}_{2} \mathrm{O}$.

Overpressure required for bubble formation:

$$
\Delta \mathrm{p}_{\mathrm{ts}}=\frac{2 \sigma}{\mathrm{R}_{0}}
$$

$\sigma$ - the surface tension of water / air at $20^{\circ} \mathrm{C}$, the value of $\sigma$ is: $\sigma=73 \cdot 10^{-3} \mathrm{~N} / \mathrm{m}$.

$\mathrm{R}_{0}$ - the radius of the bubble when it is detached from the orifice plate.

Note: $\mathrm{d}_{0}=2 \cdot \mathrm{r}_{0}$ and $\mathrm{D}_{0}=2 \mathrm{R}_{0} ; \mathrm{D}_{0}=0.1 \cdot 10^{-3} \mathrm{~m} ; \rho_{\mathrm{H} 2 \mathrm{O}}=$ $10^{3} \mathrm{~kg} / \mathrm{m}^{3}$.

Air density is determined from the state equation:

$$
\begin{aligned}
& \rho=\frac{\mathrm{p}}{\mathrm{RT}} \mathrm{kg} / \mathrm{m}^{3} \\
& \rho=\frac{10325+583 \cdot 9.81}{287 \cdot(20+273.15)}=1.26 \mathrm{~kg} / \mathrm{m}^{3}
\end{aligned}
$$

$$
\begin{array}{ll}
\mathrm{R}_{0}=\frac{\mathrm{D}_{0}}{2}=\frac{0.00164}{2}=0.00082=0.82 \cdot 10^{-3} \mathrm{~m}(5) & \Delta \mathrm{p}_{\mathrm{ts}}=\frac{2 \sigma}{\mathrm{R}_{0}}=\frac{2 \cdot 73 \cdot 10^{-3}}{0.82 \cdot 10^{-3}}=178.04 \mathrm{~N} / \mathrm{m}^{2} \\
\text { The relation becomes: } & \Delta \mathrm{p}_{\mathrm{ts}}=\rho_{\mathrm{H}_{2} \mathrm{O}} \cdot \mathrm{g} \cdot \Delta \mathrm{h}_{\mathrm{ts}} \mathrm{N} / \mathrm{m}^{2}
\end{array}
$$




$$
\begin{aligned}
\Delta \mathrm{h}_{\mathrm{ts}} & =\frac{\mathrm{p}_{\mathrm{ts}}}{\rho_{\mathrm{H}_{2} \mathrm{O}} \cdot \mathrm{g}}=\frac{178.04}{10^{3} \cdot 9.81}=18.14 \cdot 10^{-3} \mathrm{~m} \\
\Delta \mathrm{h}_{\mathrm{ts}} & \approx 18.14 \mathrm{mmH}_{2} \mathrm{O}
\end{aligned}
$$

Equation (1) becomes:

$$
\begin{aligned}
& 583=500+18.14+\Delta \mathrm{p}_{\mathrm{p}} \\
& \Delta \mathrm{h}_{\mathrm{ts}} \approx 64.86 \mathrm{mmH}_{2} \mathrm{O}
\end{aligned}
$$

The first term to the right of equation (9) is the overpressure required to overcome the hydrostatic load, the second to overcome the superficial tension and the third refers to the required pressure for an air bubble in the compressed air tank of MBG to passes through the plate into the water volume.

This experimentally determined value is much less than the pressure drop on a steel filter cartridge.

A pressure loss of $\Delta \mathrm{h}=24.92 \mathrm{mmH}_{2} \mathrm{O}$ for a 0.5 $\mathrm{mm} \varnothing$ orifice is indicated in paper [11].

This result confirms the accuracy of the experimental measurements. For $\varnothing 0.1, \Delta p=64.86$ $\mathrm{mmH}_{2} \mathrm{O}$ resulted.

\section{Conclusions}

The use of filters made of steel with orifice $\emptyset 2 \ldots 840$ $\mu \mathrm{m}$ for the production of fine air bubbles for the purpose of oxygenation of water presents the following aspects:

- The solution can be applied if there are no advanced processing technologies for obtaining very small orifices $(\varnothing<100 \mu \mathrm{m})$;
- The use of filters involves high pressure drops, $\Delta \mathrm{h}<1400 \mathrm{mmH}_{2} \mathrm{O}$, i.e. high energy consumption for pumping fluids;

- After a certain time the filter cartridge has to be cleaned or changed.

- It is advisable to use MBG with a very low pressure drop $\left(\Delta \mathrm{p}_{\mathrm{p}}=64.86 \mathrm{mmH}_{2} \mathrm{O}\right)$ which leads to low electricity consumption for compressing the air.

\section{References}

[1] Gavrilaș, I., Marinescu, N.I.: Prelucrări neconvenționale în construcția de mașini, Editura Tehnică, București(1991).

[2] Nanu, A.: Tehnologia materialelor, Editura Didactică și Pedagogică București (1977).

[3] Ceaușescu, N., Popescu, I.: Tehnologii neconvenționale, Editura Scrisul Românesc, Craiova (1982).

[4] Oprina,G., Pincovschi,I., Băran,Gh.:Hidro-GazoDinamica Sistemelor de aerare echipate cu generatoare de bule, Ed. POLITEHNICA PRES, București (2009).

[5] Pătulea,Al. S.: Influența parametrilor funcționali și a arhitecturii generatoarelor de bule fine asupra eficienței instalațiilor de aerare, Teză de doctorat, Universitatea Politehnica din București(2012).

[6] Miyahara,T., Marsuha,Y.,Takahashi,T.:The size of bubblesgeneratedfromperforatedplates, International Chemical Engineering, vol. 23, pp. 517 - 523(1983)

[7] www.alibaba.com/showroom/stainlesssteelsteel-filter-cartridge.html

[8] www.nanofiltrationtech.com 